\title{
Efecto del consumo de palo escrito, alfalfa y maíz en bloques multinutricionales sobre la calidad de la canal y carne de conejos
}

\author{
Effect of the consumption of "palo escrito", alfalfa and corn in multinutritional blocks on \\ the quality of carcass and rabbit meat
}

\author{
Coreno-Hernández Orlando orland_val23@hotmail.com, Zepeda-Bastida Armando \\ azepeda@uaeh.edu.mx, Soto-Simental Sergio sotos@uaeh.edu.mx, Ayala-Martínez Maricela \\ ayalam@uaeh.edu.mx, Ojeda-Ramírez Deyanira* dojeda@uaeh.edu.mx
}

Instituto de Ciencias Agropecuarias, Universidad Autónoma del Estado de Hidalgo. México. *Author responsible and correspondence: Ojeda-Ramírez Deyanira, Instituto de Ciencias Agropecuarias, Universidad Autónoma del Estado de Hidalgo. Ave. Universidad s/n km 1. Tulancingo, Hidalgo. México.

\section{RESUMEN}

La cunicultura es una actividad que está creciendo a nivel mundial, debido a su fácil manejo, alta tasa de reproducción y la posibilidad de generar utilidades por la venta de animales o el beneficio de proteína animal mediante el autoconsumo. Los altos costos de alimentación en la producción de conejos mediante la utilización de alimentos comerciales, hacen que se busquen alternativas de alimentación para esta especie, como puede ser el palo escrito (Dalbergia palo-escrito sp). Las hojas de esta planta contienen altas cantidades de proteína, es quizás por ello que, este género forme parte de su dieta. Se evaluó el efecto de la sustitución de la proporción de alfalfa por palo escrito en la dieta de conejos de engorda sobre la calidad de la canal y de la carne de conejos. Los resultados encontrados mostraron que el uso de palo escrito en la dieta de los conejos es totalmente perjudicial, ya que, a la primera semana de tratamiento, todos los animales murieron, a pesar de que ha sido reportado efecto benéfico en algunos otros animales. Respecto al uso de alfalfa o maíz en dietas multinutricionales, los conejos tratados con maíz mostraron una diferencia significativa en los parámetros productivos y en la calidad de la canal con respecto a los tratados con alfalfa. Es necesario seguir estudiando el palo escrito debido a que posiblemente sus metabolitos secundarios pueden tener efecto benéfico si se incluyen como aditivos.

Palabras claves: calidad de la carne, producción de conejo, Dalbergia palo-escrito.

\begin{abstract}
Rabbit breeding is an activity that is growing worldwide due to its easy handling, high reproduction rate and the possibility of generating profits from the sale of animals or the benefit of animal protein through selfconsumption. The high feed costs in the production of rabbits through the use of commercial food, make that are looked for alternatives of feeding for this species, as it can be the "palo escrito" plant (Dalbergia palo-escrito sp). The leaves of this plant contain high amounts of protein, it is perhaps for this reason that this gender is part of their diet. The effect of replacing the proportion of alfalfa per "palo escrito" in the diet of rabbits for fattening on the quality of the carcass and the meat of rabbits was evaluated. The results showed that the use of "palo escrito" in the diet of rabbits is totally harmful, since, in the first week of treatment, all the animals died, even though some beneficial effect has been reported in some other animals. Regarding the use of alfalfa or maize in multinutritional diets, the rabbits treated with maize showed a significant difference in the productive parameters and in the quality of the carcassl with respect to those treated with alfalfa. It is necessary to continue studying the "palo escrito" because possibly its secondary metabolites may have the beneficial effect if they are included as additives.
\end{abstract}

Keywords: Meat quality, rabbit production, Dalbergia palo-escrito. 


\section{INTRODUCTION}

The "palo escrito" is a tree that is mainly used by the characteristics of its wood in the elaboration of musical instruments and furniture. It is an endemic plant that is located in the states of Hidalgo, Querétaro and San Luisde Potosí; however, there are over 100 species of this genus in the various tropical zones of the world. The leaves of this plant contain high amounts of protein; it is perhaps for this reason that, in some animals, this genus forms part of their diet (Sosa et al., 2000). High feed costs in the production of rabbits through the use of commercial foods make it possible to search for feeding alternatives for this species. Alfalfa and palo escrito as a source of protein fiber in multinutritional blocks could become an alternative. In addition, not only do we want to explore the nutritional content, but also what happens to the effect of those ingredients used in the production of diets on the quality of the carcass and meat of rabbits.

The objective of the present work was to replace the proportion of alfalfa per Palo escritoin the diet of rabbits for fattening, in order to check the quality of the carcass and rabbit meat.

\section{MATERIAL AND METHODS}

Fifteen Chinchilla $x$ New Zealand $x$ California crossbred rabbits were used and they were weaned at $35 \mathrm{~d}$ of age; which were submitted to three different diets with isoprotein, isoenergetic and isofibrous multinutritional blocks; T1 fed with a diet based on corn, T2 fed with a diet based on alfalfa and T3 fed with a diet based on palo escrito. The rabbits were fed during a fattening period ( $35 \mathrm{~d}$ ). Food and water consumption were measured daily and animals were weighed once a week. Once the rabbits fulfilled the fattening period, they were transported to the Meat Workshop of the Institute of Agricultural Sciences, where they were sacrificed according to NOM-033-SAG/ZOO 2015, to obtain the weight of warm carcass, skin, viscera and organs. The carcass was stored in cooling at $4{ }^{\circ} \mathrm{C}$ for $24 \mathrm{~h}$, then dissected according to the recommendations of Blasco and Ouhayoun (1996), obtaining the weights of the cold carcass, head, front, middle, back and legs. The quality of the meat was measured in the loin, for which the $\mathrm{pH}$ (Oakton), color (Microoptix S560, I-Lab) and texture (Brookfield CT3) were determined. A completely randomized design with two treatments was used for the statistical analysis.

\section{RESULTS AND DISCUSSION}

Feeding rabbits with "palo escrito" (Dalbergia palo-escrito), as a substitute for a forage plant such as alfalfa, had a detrimental effect on the life of rabbits; due to the fact that the animals that consumed the multinutritional blocks having as basis "palo escrito", presented a mortality of $100 \%$ during the first week of the experiment. The "palo escrito" is used in several regions as a pesticide (Villavicencio-Nieto et al., 2010); however, it has been reported that this plant is consumed by cattle (Sosa et al., 2000) and by some 
monkeys (Pozos et al., 2006); as it has high protein content (40\%). Due to its high protein content it was decided to experiment as a nutritional alternative in rabbits. In treatments administered alfalfa and maize there was no mortality; the productive parameters such as the final weight and the daily weight gain were significantly higher $(P<0.01)$ in the maize treatment (Table 1), compared to alfalfa; which coincides with that reported by Acosta (2016).

Table 1. Productive parameters of rabbits fed with multinutritional blocks of maize and alfalfa.

\begin{tabular}{lll}
\hline Productive parameters & \multicolumn{1}{c}{ Maize } & \multicolumn{1}{c}{ Alfalfa } \\
\hline Initial weight $(\mathrm{g})$ & $1106.66 \pm 68.36$ & $940.00 \pm 44.75$ \\
Final weight $(\mathrm{g})$ & $1890.33 \pm 65.71^{\mathrm{a}}$ & $1532.00 \pm 43.02^{\mathrm{b}}$ \\
Daily weight gain $(\mathrm{g})$ & $22.39 \pm 0.22^{\mathrm{a}}$ & $16.91 \pm 0.14^{\mathrm{b}}$ \\
\hline
\end{tabular}

$a, b=$ Different literals in rows, indicate significant difference between treatments $(P<0.01)$.

Concerning the quality of the carcass, the rabbits that consumed multinutritional blocks based on maize had a significantly higher weight $(P<0.05)$ of the lungs, head, anterior and posterior part and bone; compared to animals treated with alfalfa (Table 2); which coincides with that reported by Acosta (2016), when using nutritional blocks based on corn, using as a binder mead.

Table 2. Quality of the carcass of rabbits fed with blocks of corn and alfalfa

\begin{tabular}{|c|c|c|}
\hline \multirow{2}{*}{ Variable } & \multicolumn{2}{|c|}{ Treatment } \\
\hline & Maize & Alfalfa \\
\hline Circunference of the hip (cm) & $21.02 \pm 1.20$ & $22.66 \pm 0.79$ \\
\hline Animal length $(\mathrm{cm})$ & $30.26 \pm 1.93$ & $30.30 \pm 1.26$ \\
\hline Hip in carcass $(\mathrm{cm})$ & $20.46 \pm 1.34$ & $19.76 \pm 0.87$ \\
\hline Carcass length $(\mathrm{cm})$ & $31.22 \pm 0.92$ & $30.66 \pm 0.60$ \\
\hline Hot carcass weight (g) & $971.33 \pm 39.61$ & $806.00 \pm 25.93$ \\
\hline Viscera weight $(\mathrm{g})$ & $513.80 \pm 25.61$ & $383.80 \pm 16.76$ \\
\hline Heart weight $(\mathrm{g})$ & $7.06 \pm 2.28$ & $5.40 \pm 1.49$ \\
\hline Liver weight (g) & $71.60 \pm 6.76$ & $43.60 \pm 4.42$ \\
\hline Lungs $(g)$ & $10.46 \pm 0.55^{a}$ & $8.80 \pm 0.36^{b}$ \\
\hline Filled digestive system (g) & $414.00 \pm 40.05$ & $309.00 \pm 26.22$ \\
\hline Skin weight (g) & $247.33 \pm 6.00^{\mathrm{a}}$ & $213.00 \pm 3.92^{b}$ \\
\hline Legs weight (g) & $34.53 \pm 4.95$ & $35.20 \pm 3.24$ \\
\hline Cold carcass weight (g) & $935.60 \pm 40.61$ & $781.60 \pm 26.58$ \\
\hline Head weight $(\mathrm{g})$ & $108.40 \pm 2.55^{a}$ & $96.40 \pm 1.67^{b}$ \\
\hline Front weight (g) & $227.86 \pm 9.67^{a}$ & $189.20 \pm 6.33^{b}$ \\
\hline Weight of the middle part $(\mathrm{g})$ & $85.86 \pm 8.92$ & $73.20 \pm 5.84$ \\
\hline Weight of back (g) & $180.53 \pm 4.86^{a}$ & $149.20 \pm 3.18^{b}$ \\
\hline Weight of the legs $(\mathrm{g})$ & $275.60 \pm 90.46$ & $321.60 \pm 59.22$ \\
\hline Weight of the kidneys $(\mathrm{g})$ & $14.00 \pm 1.93$ & $12.00 \pm 1.26$ \\
\hline Meat weight (g) & $214.13 \pm 15.28$ & $190.80 \pm 10.00$ \\
\hline Bone weight $(\mathrm{g})$ & $100.40 \pm 0.96^{a}$ & $74.40 \pm 0.63^{b}$ \\
\hline Fat Weight (g) & $3.15 \pm 0.87$ & $1.28 \pm 0.57$ \\
\hline
\end{tabular}

$a, b=$ Different literals in rows, indicate significant difference between treatments $(P<0.05)$. 
In the quality of the meat it can be observed that in color, the $a^{*}$ value was lower in the meat of the rabbits fed with corn blocks than with the alfalfa blocks, indicating colors tending to red in the case of alfalfa, because this forage has a higher antioxidant capacity compared to maize; which coincides with that reported by Dal Bosco et al., (2014) who mention that there is a greater proportion of unsaturated fatty acids when fed with rabbits with alfalfa pellets (Table 3 ).

Table 3. Color de la carne de conejos alimentados con bloques multinutricionales de alfalfa y maíz.

\begin{tabular}{|c|c|c|}
\hline \multirow{2}{*}{ Variable } & \multicolumn{2}{|c|}{ Treatment } \\
\hline & Maize & Alfalfa \\
\hline $\mathrm{L}^{*}$ & $36.23 \pm 4.06$ & $40.00 \pm 2.66$ \\
\hline$a^{*}$ & $2.00 \pm 0.11^{b}$ & $4.00 \pm 0.07^{a}$ \\
\hline$b^{*}$ & $-12.00 \pm 1.24$ & $-15.61 \pm 0.81$ \\
\hline C & $12.16 \pm 1.18$ & $16.18 \pm 0.77$ \\
\hline $\mathrm{H}$ & $21.10 \pm 17.38$ & $0.42 \pm 11.37$ \\
\hline Hardness (gf) & $902.90 \pm 346$ & $954.10 \pm 437$ \\
\hline Resilience & $0.23 \pm 0.035$ & $0.25 \pm 0.034$ \\
\hline Cohesiveness & $0.63 \pm 0.065$ & $0.63 \pm 0.054$ \\
\hline Elasticity & $3.33 \pm 0.29$ & $3.40 \pm 0.27$ \\
\hline
\end{tabular}

\section{CONCLUSION}

The productive parameters and quality of the carcass rabbits fed with maize were better than with alfalfa; but for color, the variable was a significantly higher in rabbits treated with alfalfa compared to maize. It is important to note that the substitution of "palo escrito" by alfalfa in multinutritional blocks has a detrimental effect on the life of rabbits in fattening.

\section{IMPLICATIONS}

Feeding rabbits with Palo escrito in substitution for alfalfa using multinutritional blocks, causes the animals to die in the first week of feeding; which also makes researchers assume that it has one or several compounds that are harmful to the animal; however, it is necessary to continue studying this plant, because its secondary metabolites may possibly have a beneficial effect if they are included as additives.

\section{AKNOWLEDGEMENT}

The present work was funded by SEP-PROMEP with number assignment DSA / 103.5 / 16/10281. 


\section{REFERENCES}

ACOSTA Cl. 2016. Evaluación de parámetros productivos y calidad de la canal en conejos de engorda alimentados con bloques multinutricionales. Tesis de Licenciatura. Medicina Veterinaria y Zootecnia. Instituto de Ciencias Agropecuarias. Universidad Autónoma del Estado de Hidalgo. Tulancingo de Bravo, Hidalgo. 58 p.

BLASCO A, Ouhayoun J. 1996. Harmonization of criteria and terminology in rabbit meat research. World Rabbit Science. 4:93-99. DOI: http://dx.doi.org/10.4995/wrs.1993.189

DAL BOSCO A, Mugnai C, Roscini V, Mattioli S, Ruggeri S, Castelli C. 2014. Effect of dietary alfalfa on the fatty acid composition and indexes of lipid metabolism of rabbit meat. Meat Science. 96:600-609. DOI: http://dx.doi.org/10.1016/j.meatsci.2013.08.027

POZO GM, Silva S, Carlos JC. 2006. Comportamiento alimentario de monos aulladores negros (Alouatta pigra Lawrence, Cebidae) en hábitat fragmentado en Balancán, Tabasco, México. Acta Zoológica Mexicana (nueva serie). 22:53-66. http://www1.inecol.edu.mx/azm/documentos/22_3/E-Pozo.pdf

SOSA REE, Sansores LLI, Zapata BGJ, Ortega RL. 2000. Composición botánica y valor nutricional de la dieta de bovinos en un área de vegetación secundaria en Quintana Roo. Téc Pecu Méx. 38:105-17. http://www.redalyc.org/html/613/61338201/index.html

VILLAVIENCIO-NIETO MA, Pérez-Escandón BA, Gordillo-Martínez AJ. 2010. Plantas tradicionalmente usadas como plaguicidas en el estado de Hidalgo, México. Polibotanica. 30:193-238. http://www.redalyc.org/pdf/621/62114250012.pdf 